University of Rhode Island

DigitalCommons@URI

Open Access Dissertations

1977

\title{
An Empirical Investigation of an Existential Theory as it Appears to the Elderly: The Will to Live
}

Ann M. Varna Garis

University of Rhode Island

Follow this and additional works at: https://digitalcommons.uri.edu/oa_diss

\section{Recommended Citation}

Varna Garis, Ann M., "An Empirical Investigation of an Existential Theory as it Appears to the Elderly: The Will to Live" (1977). Open Access Dissertations. Paper 1114.

https://digitalcommons.uri.edu/oa_diss/1114

This Dissertation is brought to you for free and open access by DigitalCommons@URI. It has been accepted for inclusion in Open Access Dissertations by an authorized administrator of DigitalCommons@URI. For more information, please contact digitalcommons-group@uri.edu. 
AN EMPIRICAL INVESTIGATION OF AN EXISTENTIAI THEORY AS IT APPLIES TO THE ELDERLY:

THE WILL TO LIVE

BY

ANN M. VARNA GARIS

A DISSERTATION SUBMITTED IN PARTIAL FULFILLMENT OF THE REQUIREMENTS FOR THE DEGREE OF

DOCTOR OF PHILOSOPHY

IN

PSYCHOLOGY

UNIVERSITY OF RHODE ISLAND

1977 
The purpose of the present study was to investigate the Will to Live concept as it applies to the elderly. This was accomplished by exploring the relationship among the variables of Purpose in Life; Locus of Control; Depression; and a self-rating $W i l l$ to Live scale. These are variables which, according to the literature, could be expected to be major components of the Will to Live concept.

The subjects for this study were 63 volunteers, ranging in age from 60 to 95, taken from different housing settings: nursing homes; apartments for the elderly; and private homes in the community. In order to study the will to Live concept, four instruments were administered individually to the subjects: Crumbaugh's Purpose in Life Inventory; Beck's Depression Inventory; an adaptation of James' Locus of Control scale; and a self-rating will to Live measure.

The results yielded four components, using a principle components analysis of the 53 items from the four measures. The components were: "mood state"; "locus of control"; "a level beyond"; and "energy level". Differences were found in the expected direction across the three housing groups on two of the measures and on one of the component scales. As hypothesized, a strong negative relationship was found to exist between Purpose in Life and Depression.

The results were discussed in terms of their theoretical and clinical implications. 
Freedom lies not in our triumphing over objective nature... Man is distinguished by his capacity to know that he is determined and to choose his relationship to what determines him... Nietzche spoke of ten of "loving fate". He meant that man can fact fate directly, can know it, dare it, fondle it, challenge it, quarrel with it, and love it... we are saved from the need to be the victims of $1 t . .$. We are... co-creators of our fate.

$$
\text { (May, 1969) }
$$


I would like to dedicate this dissertation on the Will to Live to my grandmother, Loretta M. Sanders, a very special person who gave freely of herself, always living life to its fullest. Upon her death, I began questioning what it was that kept people alive in stressful situations. This dissertation has been a beginning of an answering of that question. 
I would like to express my sincere thanks to the people who had a part in the development of this dissertation. I am very grateful to the members of my dissertation committee: Dr. Al Pascale, Dr. Wayne Velicer, and Dr. Allan Berman. Their continual support and encouragement was more than helpful during the long difficult process.

In the long journey I am now completing, Dr. Allan Berman has been much more than a major professor. He has been a source of encouragement and support. He has been a friend. He has, too often to mention, gone beyond the call of duty and has kept up my momentum in this Iong, tedious process. Above everything, he has cared, about my dissertation, and about me. Thank you.

I would like to express special thanks to Dr. Wayne Velicer, who helped me transform a clinical hunch into a researchable study. His ready willingness to help, as well as the expertise with which he translated clinically-phrased questions into clinically-phrased methodology, goes far beyond the skills of a statistician. He is a teacher in the highest sense of the word.

I would also like to thank Dr. Alan willoughby and Dr. Larry Grebstein, who, along with the other clinical faculty, gave me support and encouragement along the way. I have gained a great deal from knowing them as people and as clinicians. 
I would like to extend my thanks to Kathi Wolf and Mrs. Dottie Maguire, who were most helpful in obtaining access to a nursing home population for this study ... no small feat in an era of nursing home investigations, and to Mrs. Sally Edgrin, a social worker serving the west Barrington, East Providence area, who provided access to a large population of senior citizens living in the community. I would also like to thank Mrs. Nancy Johnson of the Cranston RSVP Program, who provided helpful advice and interest, and access to many interesting senior volunteers, who very willingly agreed to participate in this study.

Most importantly, I would like to extend my thanks to all 63 of the senior citizens who agreed to participate in this study, graciously welcomed me into their homes, and shared themselves: their histories, opinions, and feelings, with me.

I would like to thank so many of my friends who gave me understanding and support, in generous doses, whenever it was needed.

And Bob, my husband and best friend, who kept his head when I was losing mine, you have endured dirty dishes, dust and clutter, and countless unironed shirts ... all to allow me to follow my star, providing hugs and much support along the way. Thank you for your love. 
LIST OF TABLES . . . . . . . . . . . . . X1

INTRODUCTION. . . . . . . . . . . . . I I

Statement of the Problem ......... I 1

Significance of the Study ......... I I

Will to Live . . . . . . . . . . 1

W1Il to Live as it Relates to

Purpose in Life ..........

Frankl's Concept of Purpose in L1fe ... 4

The Purpose in Life Instrument ..... 5

Will to Live as 1t Relates to

Locus of Control ...........

The Locus of Control Instrument . . . . 9

The Subject Population-The Elderly ... 10

Purpose in Life and the Elderly .... 10

Locus of Control and the Elderly .... . 11

Depression and the Elderly ....... 11

Summary of the Problem ......... II

METHODS ........................... 13

Subjects ................ 13

The Settings ........... . . 13

Instruments .......... 15

Procedure ............ 20

RESULTS ................. 22

Correlations Between Four Dependent Measures

Across Three Groups . . . . . . . . .

Princ1ple Components Analysis . . . . . 22 
PAGE

Group Differences on Component Scales

(One, Three, Four) ........ 32

Group Differences on Will to Live Measures. • 33

Age and Physical Condition ........ 40

DISCUSSION . . . . . . . . . . . 42

Principle Components Analysis ...... 42

Group Differences ............ 44

Institutionalization of the Elderly .... 45

Range of Depression . . . . . . . 46

Purpose in Life and Depression - The

Practical Implications ......... 48

Further Implications of the Will to
Live Concept ..... . . . . . 49

Limitations of Current Findings ..... 50

Implications for Future Research . . . . 50

REFERENCES . . . . . . . . . . . 53

APPENDIX

Sample Questionnalres ....... 60 


\section{LIS'T OF TABLES}

$\underline{\text { TABLE }}$

$\underline{\text { PAGE }}$

1. Means and Standard Deviations for Three sroups on the Four Measures

2. Correlation Matrix of Four Dependent Measures across Three Groups $(N=63)$

24

3. Varimax Rotated Component Structure for W1Il to Live Items, Taken From Purpose in Life, Locus of Control. Will to Live and Depression ineasures

4. Marker Variables for the Four Components

5. Means and Standard Deviations of Three Components Across Three Groups

6. Kruskal-Wallis Analysis for Components I, III, and IV

7. Kruskal-Wallis Analysis PIL Data

8. One Way Analysis of Variance for Three Groups on Will to Live

9. The three groups ordered according to means on the Will to Live Scale Newman Keuls comparisons Indicated

10. One Way Analysis of Varlance for Three groups on Locus of Control

11. Demographic Differences Across Three Groups 41 
An Empirical Investigation of an Existential Theory As It Applies to the Elderly

The will to Iive

$$
\begin{gathered}
\text { Ann M. Varna Garis } \\
\text { University of Rhode Island } \\
1976
\end{gathered}
$$

Statement of the Problem

The purpose of this study was to explore the feasibility of the Will to Live concept as a researchable topic worthy of study in psychology. Specifically, this study investigated Will to Live among the elderly: the relationships among Will to Live, purpose in life and locus of control; and further explored the relationship between depression and purpose in life. The major assumption underlying this study was that the will to Live in the elderly was related to two measurable aspects of the Will to Live: purpose in life and locus of control.

\section{Significance of the Study}

\section{Will to Live}

The Will to Live, although commonly accepted as existing and as having an important role in peoples' lives (Hutschnecker, 1951; Eisdorfer, 1972; Gubrium, 1972; Curtin, 1972; Clark, 1974; Seligman, 1975; May, 1969), has been neither clearly defined nor empirically investigated. May has pointed to the tendency to interpret the concept of "Will" in less than "scientific" terms, an issue intimately related to the purpose of this study. 
Toward the end of analysis the therapist may find himself wishing that the patient were capable of more "push", more "determination" ... this wish eventuates in remarks to the patient: "People must help themselves" ... "You have to try". Such interventions are seldom included in case reports, for it is assumed that they possess neither the dignity nor effectiveness of interpretation. often an analyst feels uncomfortable about such appeals to volition as though he were using something he didn't believe in, and as though this would have been unnecessary had only he analyzed more skillfully (May, 1969, p. 197).

The alternate side of the Will to Live, a passive surrender to death, a syndrome much resembling that of depression, has been researched in the laboratory with various animal populations. These studies (Ieftcourt, 1973; Seligman and overmeir, 1967; Weiss, 1971; Richter, 1959) have looked primarily at the control - helpless dimension in studies of persistence under stress. In the human population, the area has been explored anecdotally and through medical and Iiterary case histories (Leftcourt, 1973; Frankl, 1963; Hutschnecker, 1951; Schneidman, 1973).

Hutschnecker (1951) focused on the interaction between physical and emotional well being, and suggested that lack of emotional health can lead to a variety of physical ailments, including the ultimate ailment, death. other investigators have suggested similar notions, such as Ginspag (1973), who concluded that heart attacks appear, at times, to be socially sanctioned suicides. Hutschnecker's understanding of the will to Iive appears to be an analytic one involving two instincts eros, a positive-creative instinct, 
and thanatos, a destructive or death instinct.

Whether we call them attraction and repulsion, fusion and fission, friendship and strife, love and hate, peace and war, good and evil, the concept is the same: two forces pitted against each other in the vastness of the universe, in the miniature cosmos of the atom and in the inner world of every man....

(Hutschnecker, 1951, p. 27)

\section{Will to Live As It Relates to Purpose in Life}

Hutschnecker (1951) has also described the Will to

Live in terms very similar to those which self-actualization theorists might use. He has suggested that each individual, throughout life, strives toward some goal, whether consciously or unconsciously. When that goal is achieved or when the individual becomes convinced that the goal cannot be reached, Iife ceases to have meaning, and he dies.

When the longing for peace outweighs the joy of struggle for achievement, when the determination to seek peace becomes irreversible and conclusive, then we die... (Hutschnecker, 1951, p. 51)

May, an existential theorist, has also dealt with

the issue of the consequences of loss of purpose in life.

...the human being cannot live in a condition of emptiness for very long; if he is not growing toward something, he does not merely stagnate; the pent up potentialities turn into morbidity and despair, and eventually into destructive activities.... (liay, 1969, p. 28)

Maslow posited the existence of a will toward growth, a will toward the actualization of human potentialities (Hall and Lindzey, 1967); a force similar to this, toward a goal such as continued growth and development, is 
one way in which the will to Live could be conceptualized. This will has been described as:

Mnot strong and overpowering and unmistakable
iike the instincts of animals. It is weak and
delicate and subtle and easily overcome by
pressure... (Hall and Lindey, 1967, p. 327)

Also, according to Maslow, these higher needs can be fulfilled only if more basic, survival needs are first fulfilled. On the other hand, it could be argued that it is the higher needs, the will toward growth or purpose in life, that in times of stress helps man to accomplish the more basic tasks necessary for survival ... in a concentration camp, in a hospital, in the retirement years. This position is, of course, consistent with Frankl's theory of purpose in life.

\section{Frankl's Concept of Purpose in Life}

Frankl's concept of purpose in life was developed during his captivity in a World War II concentration camp. In attempting to answer the question of what it is that keeps people from committing suicide in spite of highly aversive, stressful situations, he postulated the notion of purpose or meaning in life as being "...a basic human motivating force, best described as spiritual..." (Crumbaugh and Maholick, 1964). According to Frankl, there is an internal psychological force called purpose in life which makes life's difficulties endurable. In addition, it is through acceptance of unchangeable social and biological forced and situations that man is able to recognize the freedoms which do exist within a situation (Maddi, 1968). When purpose in life within a given 
situation is not found, the individual can be expected to become existentially frustrated, which may in turn lead to psychopathology (Crumbaugh and Maholick, 1964). Frankl has described the reaction associated with the loss of purpose in life:

The prisoner who had lost faith in the future, his future was doomed. With his loss of belief, he also lost his spiritual hold; he let himself decline and became subject to mental and physical decay. Usually this happened quite suddenly... he simply gave up...there he remained, lying in his own excreta, and nothing bothered him anymore (Frankl, 1963, p. 118).

The Purpose in Life Instrument

An instrument to measure purpose in life was developed by Crumbaugh; its defined purpose was to measure the degree to which people experience a sense of meaning and purpose in their lives. Crumbaugh's PII has been administered to various categories of normal and psychiatric populations. It was found to discriminate between normal and psychiatric populations with a high degree of accuracy (Crumbaugh, 1968). The PII shows a significantly negative correlation with the Depression Scale of the MMPI $(r=-.65)$; however, socioeconomic factors such as income and occupation showed no significant relationship to PIL scores. No consistent sex differences have been reported. Crumbaugh reported that the extremes of age have not been covered in the population samples and that a significant relationship may exist between PII scores and old age (Crumbaugh and Maholick, 1964). 
Specifically relating to the elderly sample used in this study, it should be noted that relationships have been found to exist in elderly samples between age, sex, socioeconomic status, and morale, a concept related to purpose in life (Palmore, 1969; Riley and Foner, 1968, Blau, 1973).

\section{Will to Live As It Relates to Locus of Control}

Hutschnecker and others have also discussed the loss of the will to Live in terms of a reaction to powerlessness as a way of seeking escape from a situation which cannot be changed or endured. A notable example of this reaction is the recent illness of Richard Nixon.

Experts in psychosomatic medicine...believe there is ample evidence that a profound change in a person's life that leads to a sense of futility and helplessness can precipitate illness to which he is predisposed. Nixon seems to fit the picture. (Clark, 1974, p. 28)

May, like Hutschnecker, also related the lack of Will to Live to man's sense of powerlessness in effecting changes in his life or in the world around him.

... when a person continually faces dangers he is powerless to overcome, the final line of defense is at last to avoid even feeling the dangers (May, 1969, p. 28).

Experimental work with rats, cockroaches, and other animals has given support to the notion that life is dependent upon control or perceived control that an organism has in a stress situation. Leftcourt (1963) reviewed the literature on perceived control in aversive situations including an anecdotal report about a chronic psychiatric patient, a report 
about Richter's serendipitious discovery of a sudden death syndrome in rats, and Seligman's concept of depression as "learned helplessness".

Leftcourt's account of a chronic, hospitalized psychiatric patient reported that in response to being transferred from a more "hopeless unit" to a more open "exit ward", a patient became more socially outgoing, showing obvious improvement; when returned to the "hopeless unit" after redecoration of that unit had been completed, the patient died.

... an autopsy revealed no pathology of note, and it was whimsically suggested at the time that the patient had died of despair (Leftcourt, 1963, p. 422).

Curt Richter's experiment with rats (1959) noted that after various procedures a number of the animals demonstrated a series of unusual movements which culminated in death. The phenomenon was particularly striking in one of Richter's swimming endurance procedures. In this procedure Richter concluded that handling restraint was the primary cause of the unexpected sudden deaths.

...handling, while producing arousal
among wild rats, also prevented any
instrumental activity that could result
in escape from the aversive experience.
If rats were allowed to escape just once,
the sudden death phenomenon was eliminated. (Leftcourt, 1963, p. 421)

Richter has defined the resultant effect upon the rats as being "hopelessness". 
The situation of these rats is not one that can be resolved by either fight or flight; it is rather one of hopelessness... they seem to literally give up.

(Richter, 1959, p. 308)

This helpless-hopeless-sudden death sequence was also observed by Seligman and Overmeir (1967) who placed dogs in a shuttle apparatus, some of which had and some of which had not been previously subjected to inescapable shock. There were marked differences between the two groups of animals. The dogs which had been inescapably shocked responded in a passive, maladaptive fashion. In further studies, Seligman et. al (1968) determined that animals can be "innoculated" against the effects of inescapable aversive stress by first exposing the organisms to similar aversive situations from which they are able to escape.

Most notable of the studies on the detrimental effects of helplessness in a stressful situation was the Weiss study (1971), a replication of the well-known Brady. (1958) "executive monkey" study. Brady had concluded from his study that being in a decision-making position in an aversive situation was more stressful for an organism than being the passive recipient of aversive stimulation. His conclusions, based upon results in which "executive monkeys" developed severe gastric ulcers, were not, however, supported by Weiss' replication. Weiss suggested that the reason for the conflicting findings was the non-randomized subject selection of Brady's "executive" organisms. Weiss found the passive, impotent animal to be the one which suffered most, 
physiologically, from the experimentally-induced stress. The conclusion which leftcourt (1963) drew from a review of studies similar to these was that:

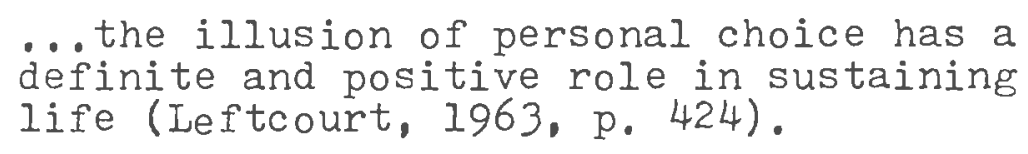

Choice, or the illusion of choice, is, then, an integral part of the ability to survive a stressful situation. It is suggested that survival, when studied from a human perspective, is appropriately understood to include purpose in life in addition to control, or the illusion of control. Frankl's concept of purpose in life, combined with a locus of control measure, provided a useful framework for this study.

\section{The Locus of Control Instrument}

The concept of locus of control developed by Rotter (1966) deals with an individual's perception of contingency relationships between his own behavior and the events which follow that behavior. If an individual interprets a consequence as being the result of luck, fate, under the control of others, or as being unpredictable in nature, that individual is said to have a belief in external control. If an individual interprets a consequence as being contingent upon his own behavior or personal characteristics, the individual is said to have a belief in internal control.

The locus of control instrument utilized in this study is a measurement of generalized sense of locus of control, rather than an instrument to measure a more personalized sense of locus of control. 
The Subject Population - The Elderly

Psychological state has been found to be critically important to survival in a variety of stressful situations: concentration camps, prisons, natural disasters, life threatening illness, and old age. The will to Live is frequently considered the key to survival in these situations. Although a continuum of Will to Live/lack of Will to Live is understandably present in all segments of the population, from reports of those who work with the elderly (Curtin, 1972; Levin, 1963; Wolfe, 1974) the extremes of the continuum are much more visible in the elderly population. Indeed the elderly are under a great many stresses, necessary housing readjustments, physical illness, financial stress, interpersonal losses of spouse and friends, etc. Neugarten (1964) has more generally described the degree of stress relating to old age as reflecting the degree of discontinuity with the individual's past, suggesting that to the extent that discontinuity with the past exists, stress exists. In light of the many stresses imposed upon the elderly, they were selected as the subject population for this study, judging them to be a key population worthy of study with regard to the concept of Will to Live.

\section{Purpose in Life and the Elderly}

The elderly population has not been previously studied with regard to the Purpose in Life variable, although Crumbaugh (1964) suggests this as a meaningful area of research (Huych, 1974; Curtin, 1972), and others have suggested that emphasis on maximizing human potential of the elderly is necessary for adjustment of the elderly. Dowd (1975) has suggested that 
lack of power, related to the level of functioning, is the precurssor to disengagement, withdrawal, and the related depression of the elderly.

Locus of Control and the Elderly

Palmore and Luikart (1972) found internal locus of control to be the second best predictor of life satisfaction among those over the age of 60 .

Kuypers (1972) indicated that elderly internals generally cope better and are less defensive than elderly externals. Felton and Kahana (1974) in investigating locus of control among institutionalized aged found that in that population external rather than internal locus of control was found to relate to "good adjustment".

Depression and the Elderly

Levin (1963) reports that the incidence of depression and suicide increase with age. He questions whether many of the characteristics of "disengagement" in the elderly are, in fact, manifestations of depression.

Smith (1972) discusses the prevalence of depression and suicide in the elderly population.

The incidence of suicide is highest in the aged in our country. Twenty-five percent of all suicides occur in persons over 65 years of age (Smith, 1972, p. 21).

\section{Summary of the Problem}

The major hypothesis explored in this study was as follows. Two major measurable aspects of the Will to Live are 
locus of control and purpose in life. Locus of control was operationally defined as that which is measured by an abbreviated form of the James' Internal-External Locus of Control Measure. Purpose in Life was operationally defined as that which is measured by Crumbaugh's Purpose in Life Inventory. The predictions were as follows:

1. Items from the Locus of Control measure and the Purpose in Life measure will together form a component identifiable as the hypothesized Will to Iive component.

2. An inverse relationship exists between depression, as measured by the Beck Depression Inventory and Crumbaugh's Purpose in Life measure.

3. The Will to Live measures are related to differences in living conditions such that individuals more completely integrated into the community would possess a higher level of Will to Iive, as measured by both the self-rating Will to Live measure and by the component Purpose in Life and Locus of Control measures . 
METHOD

$\underline{\text { Subjects }}$

Sixty-three ambulatory, male and female volunteers, ranging in age from 60 to 95 years, served as subjects. Subjects were obtained through community workers who had personal contact with groups of elderly people in Rhode Island. Included among these workers were the director of the Cranston RSVP Program, a community worker in East Providence who ran discussion groups for senior citizens, and the social director of a nursing home in Chepachet, Rhode Island. The community workers helped select subjects in the community who could carry on a conversation of some length and complete the necessary questionnaires. The community workers notified subjects that the experimenter would be contacting them. Subjects living in the community were contacted by phone to make an appointment for an interview, usually held in the subject's home. Subjects were divided into three experimental groups on the basis of the degree of independence associated with their living conditions: nursing homes, apartments for the elderly, and private residences in the community.

\section{The Settings}

The nursing home was a large three-story frame building in a rural Rhode Island community. Rooms were double occupancy; halls and lobby areas were somewhat crowded with patients in wheelchairs. The atmosphere of the nursing 
home seemed friendly and the morale of the patients reasonably good. Meals were served in the patients' rooms or on trays to wheelchair patients in the hall. There was no room in the facility suitable for social gatherings or as a daytime lounge for the patients. The grounds were pleasant and shady, with a large lawn.

The subjects in this group ranged in age from 60 to 95 , with a mean age of 78.6 years. The mean number of Self-Report Physical Problems in this group was 2.05. The group was made up of thirteen females and seven males. The mean length of years at present residence was 2.1 years. The apartment complexes for the elderly were either of the high-rise type or the smaller two- or three-story variety. They tended to be located very close to shopping areas, for example, on a residential street, one block from a major grocery store. The buildings themselves had long corridors, the doors of which were frequently left ajar, making the atmosphere much like that of a college dormitory, with a good deal of visible social interchange between the residents of a given section of the corridor. The apartments were $2 \frac{1}{2}$ rooms (living room-kitchen, bedroom, bath) with linoleum floors, frequently covered by the tenant with sections of carpeting. The tenants generally reported being content with their housing, frequently commenting on how lucky they had been to be able to get into the housing, about long waiting lists, political favoritism, etc. Among the complaints about the apartments were concerns about privacy and security 
aspects of the facility, as well as occasional complaints about house rules and regulations.

Subjects in this group ranged in age from 65 to 83 , with a mean age of 72.8 years. The mean number of SelfReported Physical Problems was 2.4. This group was composed of 16 females and two males. The mean number of years at the present residence was 5.9 years.

Subjects in the third group lived in either private homes or apartments located around the community. The neighborhoods ranged from middle-middle class to lower-middle class. Apartments tended to be small, with a single bedroom, a small kitchen, and a small living room. Houses were of the bungalow type, and were well maintained in quiet residential neighborhoods.

Subjects in this group ranged in age from 60 to 91 , with a mean age of 70.4 years. The mean number of SelfReported Physical Problems was 2.4. This group was made up of 17 females and eight males. The mean number of years at present residence was 20.4 years.

\section{Instruments}

Five inventories were used to gather information from the subjects. The instruments are described in their order of presentation to the subjects.

1. Demographic Data Form: This included a checklist measure for self-rating of current physical status, as well as relevant background data such as age, sex, educational history, occupa- 
tion, marital status, living situation, etc. In addition, several direct questions were included concerning the subjects' perception of a stressful situation at this stage of his/her life and a self-rated prediction of how he/she would hande such a situation.

2. Purpose in Life Inventory: This is a 20-item attitude scale designed by Crumbaugh (1968) to measure the "degree to which a person experiences a sense of meaning and purpose in life." The scale is presented in a Likert format, each item having a 7-point spread, providing a total possible point spread of 20 (low purpose) to 140 (high purpose). Average scores tend to skew toward the purposeful end of the scale, with average scores from various samples as follows: successful businessmen and professionals - 118.9; active Protestant parishioners - 114.3; college undergraduates - 108.5; indigent hospital patients - 106.4; outpatient neurotics - 93.3. Split half reliability obtained by Crumbaugh showed a correlation coefficient of .85 with an $N=120$. Criterion validity is demonstrated through a .47 correlation of PIL scores with minister ratings and $a .38$ correlation with therapist ratings for the respective parishioner and outpatient populations. Crumbaugh obtained a -.65 correlation between the PII and the Depression Scale of the MMPI.

3. Depression Inventory: Beck et. al (1961) This is a 2l-item inventory based upon 21 categories selected on the basis of systematic observations, representative of attitudes and symptoms characteristic of the depression syndrome. Each 
item consists of a series of four to five statements relevant to that symptom category, ranked from neutral to maximum severity of that symptom. The item categories are as follows:

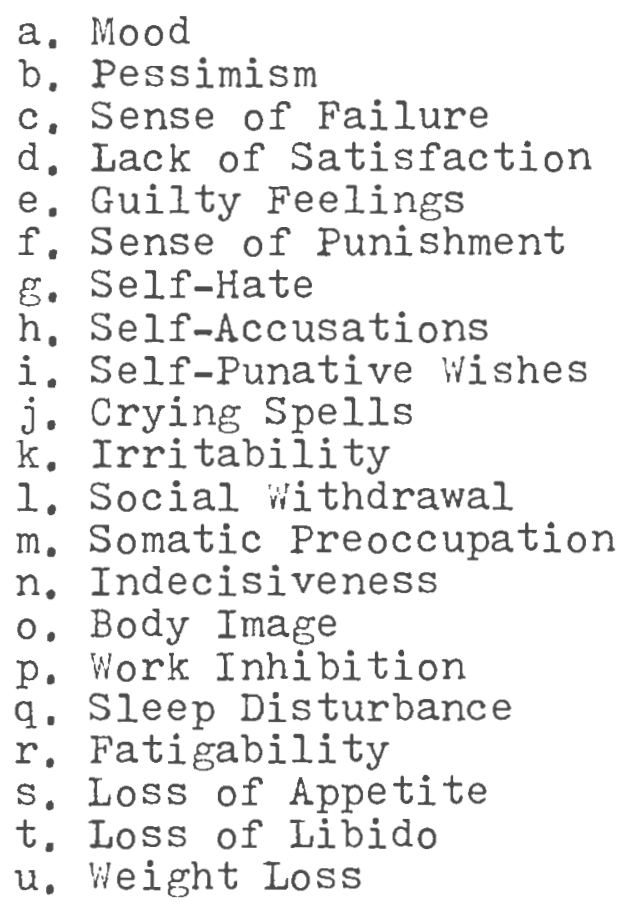

The instrument was developed utilizing the population of routine admissions to the psychiatric outpatient departments of a university hospital and a metropolitan hospital in the Philadelphia area. Within this population there was a predominance of white, lower socioeconomic (Hollingshead Index of Social Position, Classes IV and V) patients between the ages of 15 and 44. Patients with organic brain syndromes and mental deficiency were excluded Irom the study. External criterion, either immediately before or immediately after the administration of the inventory, the patient was seen by one of four experienced psychiatrists who participated in the study, and was rated on a 4-point scale as to depth of depression present. A Pearson Biserial $r$ was used and obtained 
significant correlations $(.65$ and .67$)$ between scores on the depression inventory and clinical judgments as to depth of depression. Norms of the Depression Inventory, as associated with various degrees of depression, according to Depth of Depression Ratings by psychiatrists were as follows: No depression - mean score $=10.9 ; \mathrm{Mild}-$ mean score $=18.7 ;$ Moderate depression - mean score $=25.4$; Severe depression mean score $=30.0$.

4. Locus of Control Scale: A 60-item scale was developed by James (1957; 1963) to measure internal-external locus of control as described by Rotter (1966). The ll-item adaptation of James' scale, utilized in this study, was suggested by MacDonald and Tseng (1974), in a factor analytic study of James' and Rotter'S I-E scales. Factor analysis showed each scale to have one general factor which accounted for much of the variance; in the Rotter scale, accounting for $15 \%$ of the variance; in the James' scale, accounting for $23 \%$ of the variance. The data suggests that 11 items of James' scale may constitute a factorally pure, unidimensional short test of internal-external locus of control as a generalized expectancy of the subject. It is further suggested that this ll-item test may provide a more equivalent cross-sex measure of the dimension than either the Rotter or James' scales as they presently exist. Development of this short test will require further psychometric study. One area of possible concern which should be noted is the unidirectional way in which all the items of the James' scale are phrased, which may lead to 
response blas. The norms for the James' scale, obtained with a college population, with a theoretical range of 0 to 90 , were as follows: range 8-82, with a mean score of 37 and a standard deviation of 12. No normative data is avallable for the adaptation of the James' scale utilized in this study. The theoretical range of the adapted scale is from 0 to 33.

5. W11l to L1ve Measure: Th1s is a measure which was specifically developed for this research. The measure consists of a single item and was designed to be a self-rating measure of the will to live. The directions for the measure were:

The human w1ll has been sald to be a strong force in people's lives, helping them through very difficult situations. helping them accomplish goals which they ordinarily would not have been able to achieve.

With 100 being the most "w1ll" anyone could have, and 0 being the least, how much "will" would you say that you have at the present time? Place an " $X$ " at the appropriate spot on the line.

The format of the measure is an adaptation of the Wolpe Subjective Units of Disturbance Scale (SUDS) (1969), used to obtain state measures of anxiety. It was necessary to develop an instrument such as this because no measure had been previously constructed to measure the Will to Live. This measure, like the adaptation of the James' scale, will require further psychometric study. At present there is no established reliability data for this measure; development of this data is not within the scope of this study. The SUDS model has proven an efficient means of measuring anxiety in many studies (Lifrak, 
1971; Prochaska, 1971) and is used here to investigate a new variable, the Will to Live. The scale itself consists of a line approximately ten inches in length with the numbers 0 and 100 marked under each end of the line. The subject was instructed to place an " $X$ " on the spot on the line which he felt most closely represented his present level of "will". The inventory was scored with a ruler, measuring the distance from the $O$ point to the $X$ mark. That score was then converted into a percentage score, such that the highest possible score was 100 and the lowest was 0 .

\section{Procedure}

The interviews and instruments were administered individually to the subjects in the following order, Demographic Data Form, Purpose in Life Scale, Depression Inventory, Locus of Control Measure, and Will to Live Measure. Subjects had been contacted by phone for an appointment. The interview was usually conducted in the home of the subject. Interviews lasted for varying lengths of time from one-half hour to an hour and one-half. The time differences in administration related to the extent to which the subjects and $I$ extended the interview beyond the required information into a more personal, social visit. Frequently, after the necessary data had been gathered, tea or colfee was offered, and sharing of family photos and other personal momentoes seemed to naturally follow. In just one visit, I felt I had come to understand many of the subjects quite well: to share their 
wit, their friendship, their loneliness, as well as their strengths in the face of adversity of many sorts. 


\section{RESULTS}

The following varlables: Purpose in Life, Locus of Control, Will to Live, and Depression were measured across three groups of elderly people: Group one living in a nursing home setting. Group Two living in apartment complexes for the elderly, and Group Three living in non-specialized housing in the community. Table 1 presents the means and standard deviations for three experimental groups on the four dependent measures.

Correlations Between Four Dependent Measures Across Three Groups

In order to determine the relationship among the four administered measures, both as a preliminary to the principle components analysis and to test the hypothesis regarding the relationship between Purpose in Iife and Depression, a Pearson $r$ correlation was performed on the scores for the four variables, combining the three groups $(\mathrm{N}=63)$. The correlation matrix is presented in Table 2. A correlation of -.83 was obtained between the Purpose in Life and the Depression measures. No other significant correlations were found.

\section{Principle Components Analysis}

In order to evaluate the hypothesized interrelationship among the components underlying the four measures, a principle components analysis was performed, using the 53 items of the four major measures, with one 1tem from the will to Live measure, 20 items from the Purpose in Life measure, II 
TABLE 1

Means and Standard Deviations for

Three groups on the Four Measures

GROUPS

I

II

III PRIVATE

NURSING HOME AFARTYENTS HOMES

\begin{tabular}{|c|c|c|c|}
\hline \multirow{2}{*}{ W11I to L1v } & 65.250 & 70.833 & 82.359 \\
\hline & 28.644 & 15.170 & $16 \cdot 388$ \\
\hline \multirow{2}{*}{ Purpose in Life ${ }_{\text {S.D. }}^{X}$} & 94.649 & 113.444 & 109.200 \\
\hline & 21.827 & 7.114 & 20.207 \\
\hline \multirow{2}{*}{$\begin{array}{r}\text { Locus of Control } \\
\text { S.D. }\end{array}$} & 22.149 & 20.722 & 18.480 \\
\hline & 4.997 & 6.124 & 4.528 \\
\hline \multirow{2}{*}{ Depress10 } & 8.850 & 4.055 & 6.240 \\
\hline & 8.125 & 3.244 & 5.974 \\
\hline
\end{tabular}

* higher scores indicate more W11l to Live; greater Purpose in Life; more external Locus of Control; and a higher degree of depression 
TABLE 2

Correlation Matrix of Four Dependent Measures across Three Groups $(\mathrm{N}=63)$

Purpose Depression Locus W111

Purpose in Life

Depression

$-0.8291$

Locus of Control -0.2725

0.1133

Will to Live

$-0.2664$

$-0.2327$

$-0.2487$ 
1 tems from the Locus of Control measure and 21 tems from the Depression measure. The principle components analysis was performed on the $53 \times 53$ matrix of intercorrelations and four components were extracted. The number of components was determined by the partial correlation method (Velicer, 1976). A varimax rotation was performed on the component pattern; Table 4 contains the marker variables for each of the four components. The four components together account for $42.8 \%$ of the total variance.

Component 1 could be described as being bipolar in nature, containing within it items drawn from the Depression and Purpose in Life measures. The Depression 1tems have the higher positive component loadings, and the Purpose in Life items have lower, negative loadings. This component centers around 1ssues associated with the depression syndrome. An appropriate label for this component would be "mood state". This component accounted for $24 \%$ of the unrotated variance.

Component 2 contained items relating only to locus of control from the Locus of Control measure. These findings identify the Locus of Control measure as the only one of the a prior scales which held up in terms of its construct validity. The label given to this component was "locus of control". This component accounted for $7.4 \%$ of the unrotated variance.

Component 3 very closely approximated the hypothesized will to Live component. It contained items relating to a sense of 


\section{TABLE 3}

Varimax Rotated Component Structure for W111 to Live Items, Taken From Purpose in Life, Locus of Control, W11l to Live and Depression Measures

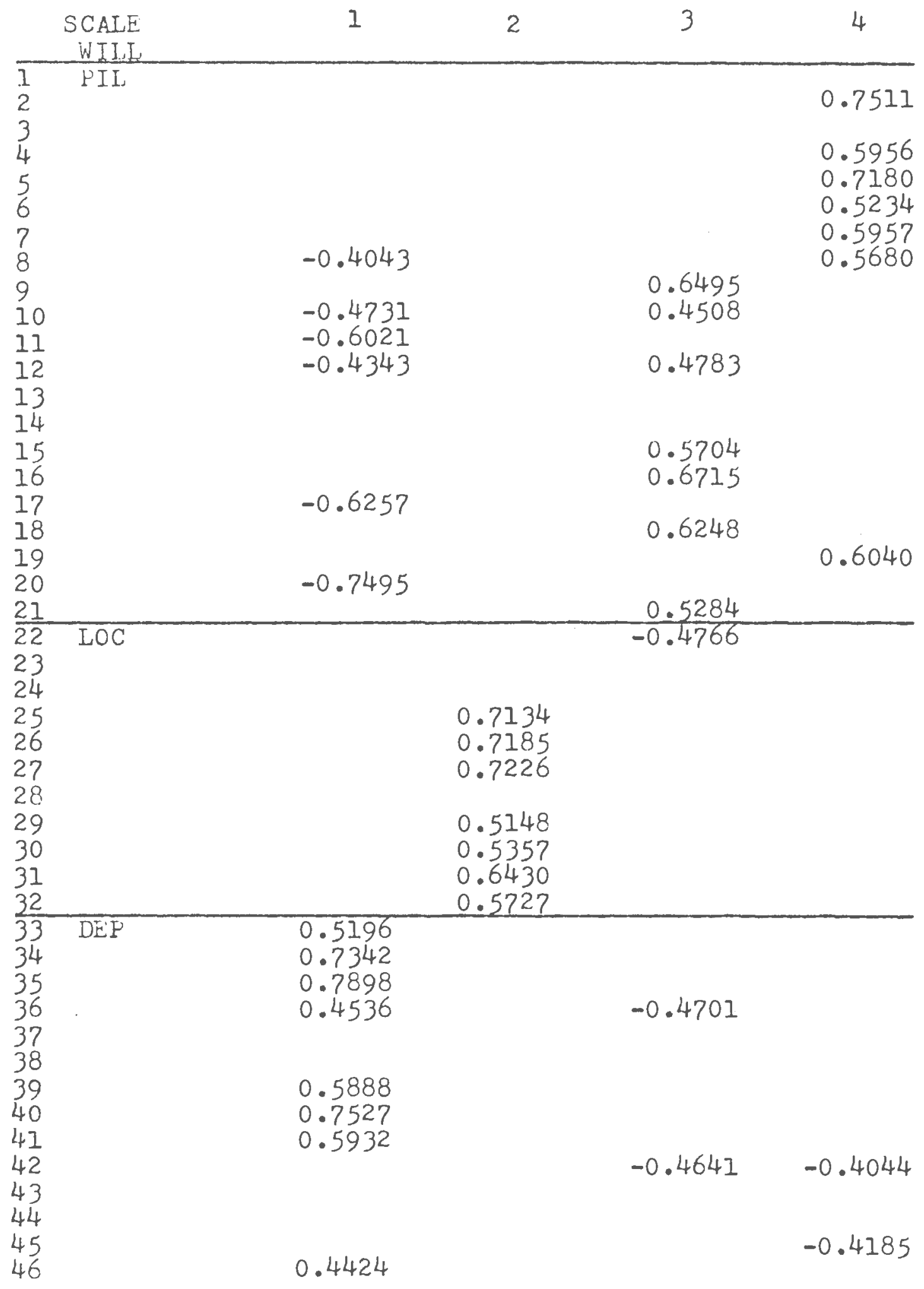


Table 3 (continued)

$\begin{array}{cc}47 & 1 \\ 48 & 0.4006 \\ 49 & 0.6924 \\ 50 & 0.6538 \\ 51 & 0.5064 \\ 52 & \end{array}$

2

3

4

$-0.6883$

$-0.4340$

Eigen Values*

12.7448

3.9378

3.1703

2.8420

$\%$ Variences Accounted for*

$24 \%$

$7.4 \%$

$5.98 \%$

$5 \cdot 35 \%$

*Unrotated 


\section{TABLE 4}

Marker Variables for the Four Components

\begin{tabular}{|c|c|c|}
\hline Load1ng* & Measure & Item \\
\hline 0.7898 & Dep & $\begin{array}{l}\text { I don't feel like a fallure/ I feel } \\
\text { I have falled more than the average } \\
\text { person. }\end{array}$ \\
\hline 0.7527 & Dep & $\begin{array}{l}\text { I don't feel I am any worse than } \\
\text { anyone else/ I am very critical } \\
\text { of myself for my weaknesses or } \\
\text { mistakes. }\end{array}$ \\
\hline-0.7495 & PIL & $\begin{array}{l}\text { Facing my daily tasks is a source } \\
\text { of pleasure and satisfaction/ a } \\
\text { painful and boring experience }\end{array}$ \\
\hline 0.7342 & Dep & $\begin{array}{l}\text { I am not particularly pessimistic } \\
\text { or discouraged about the future. }\end{array}$ \\
\hline 0.6924 & Dep & $\begin{array}{l}\text { I don't get any more tired than } \\
\text { usual/ I get tired more easily } \\
\text { than I used to. }\end{array}$ \\
\hline 0.6538 & Dep & $\begin{array}{l}\text { My appetite is no worse than usual/ } \\
\text { My appetite is not as good as } 1 \mathrm{t} \\
\text { used to be. }\end{array}$ \\
\hline-0.6257 & PIL & $\begin{array}{l}\text { With regard to sulcide, I have } \\
\text { thought of it seriously as a way } \\
\text { out/ Never given it a second thought. }\end{array}$ \\
\hline-0.6021 & PII & $\begin{array}{l}\text { If I should die today, I would } \\
\text { feel that my life has been very } \\
\text { worthwhle/ Completely worthless. }\end{array}$ \\
\hline 0.5932 & Dep & $\begin{array}{l}\text { I don't have any thoughts of harm- } \\
\text { ing myself/ I have thoughs of } \\
\text { harming myself but would not carry } \\
\text { them out. }\end{array}$ \\
\hline 0.5888 & Dep & $\begin{array}{l}\text { I don't feel disappointed in myself/ } \\
\text { I am disappointed in myself. }\end{array}$ \\
\hline
\end{tabular}

Component 2. "Locus of Control"

$0.7226 \quad$ LOC

I have usually found that what is golng to happen wlll happen regardless of my actions. 
Table 4 (continued)

$\begin{array}{lll}\text { Loading } & \text { Measure } & \text { Item } \\ 0.7185 & \text { LOC } & \begin{array}{l}\text { When things are going well for me } \\ \text { I consider it due to a run of } \\ \text { good luck. }\end{array} \\ 0.7134 & \text { LOC } & \begin{array}{l}\text { It isn't wise to plan too far } \\ \text { ahead because most things turn } \\ \text { out to be a matter of good or } \\ \text { bad fortune anyhow. }\end{array} \\ 0.6430 & \text { LOC } & \begin{array}{l}\text { I think that life is mostly a } \\ \text { gamble. }\end{array} \\ 0.5727 & \text { LOC } & \begin{array}{l}\text { Many times I feel that I have } \\ \text { little influence over the things } \\ \text { that happen to me. }\end{array} \\ & & \begin{array}{l}\text { Success in dealing with people } \\ \text { seems to be more a matter of the } \\ \text { other person's moods and feelings } \\ \text { at the time rather than one's own } \\ \text { actions. } \\ 0.5357\end{array} \\ & \text { LOC } & \begin{array}{l}\text { There is not much use in worrying } \\ \text { about things, what will be will be. }\end{array}\end{array}$

Component 3. "A Level Beyond"

0.6715 PII With regard to death I am prepared and unafraid/ Unprepared and frightened.

0.6485 PIL In achieving life goals, I have made no progress whatever/ Progressed to complete fulfillment.

$0.6248 \quad$ PIL

I regard my ability to find a meaning, mission or purpose in life as very great/ Practically none.

$0.5704 \quad$ FIL

Concerning man's freedom to make his own cholces. I believe man is absolutely free to make all life cholces/ Completely bound by IImltations of heredity and environment.

0.5284

PIL

I have discovered no mission or purpose in I1fe/ Clear cut goals and a satisfying life purpose. 


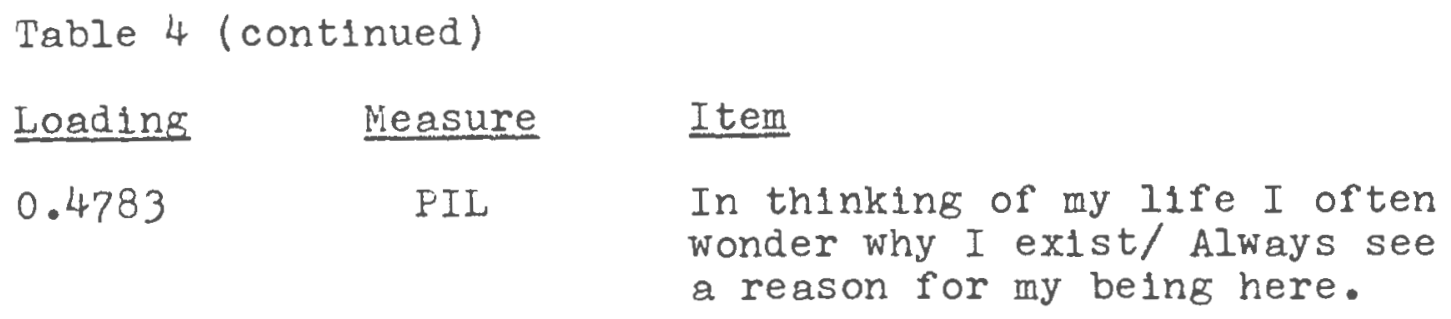

Loading

0.4783

PII

\section{Item}

In thinking of my life I of ten wonder why I exist/ Always see a reason for my being here.

\begin{tabular}{|c|c|c|}
\hline 0.7511 & FIL & $\begin{array}{l}\text { I am usually completely bored/ } \\
\text { Exhuberent and enthusiastic. }\end{array}$ \\
\hline 0.7180 & PIL & $\begin{array}{l}\text { My personal existence is utterly } \\
\text { meaningless and without purpose/ } \\
\text { Very purposeful and meaningful. }\end{array}$ \\
\hline-0.6883 & Dep & $\begin{array}{l}\text { I can work about as well as before/ } \\
\text { It takes extra effort to get } \\
\text { started at doing something. }\end{array}$ \\
\hline 0.6040 & PIL & $\begin{array}{l}\text { My life is in my hands and I am in } \\
\text { control of } 1 \mathrm{t} / \text { out of my hands and } \\
\text { controlled by external factors. }\end{array}$ \\
\hline 0.5957 & PIL & $\begin{array}{l}\text { After retiring I would do some of } \\
\text { the exciting things I have always } \\
\text { wanted to. }\end{array}$ \\
\hline 0.5956 & PIL & $\begin{array}{l}\text { In life I have no goals or aims at } \\
\text { all/Very clear goals and alms. }\end{array}$ \\
\hline 0.5680 & PIL & $\begin{array}{l}\text { If I could choose I would prefer } \\
\text { never to have been born/ Like } 9 \\
\text { more lives just like this one. }\end{array}$ \\
\hline
\end{tabular}

* from Varimax rotated pattern. 
TABLE 5

Means and Standard Deviations of Three Components Across Three Groups

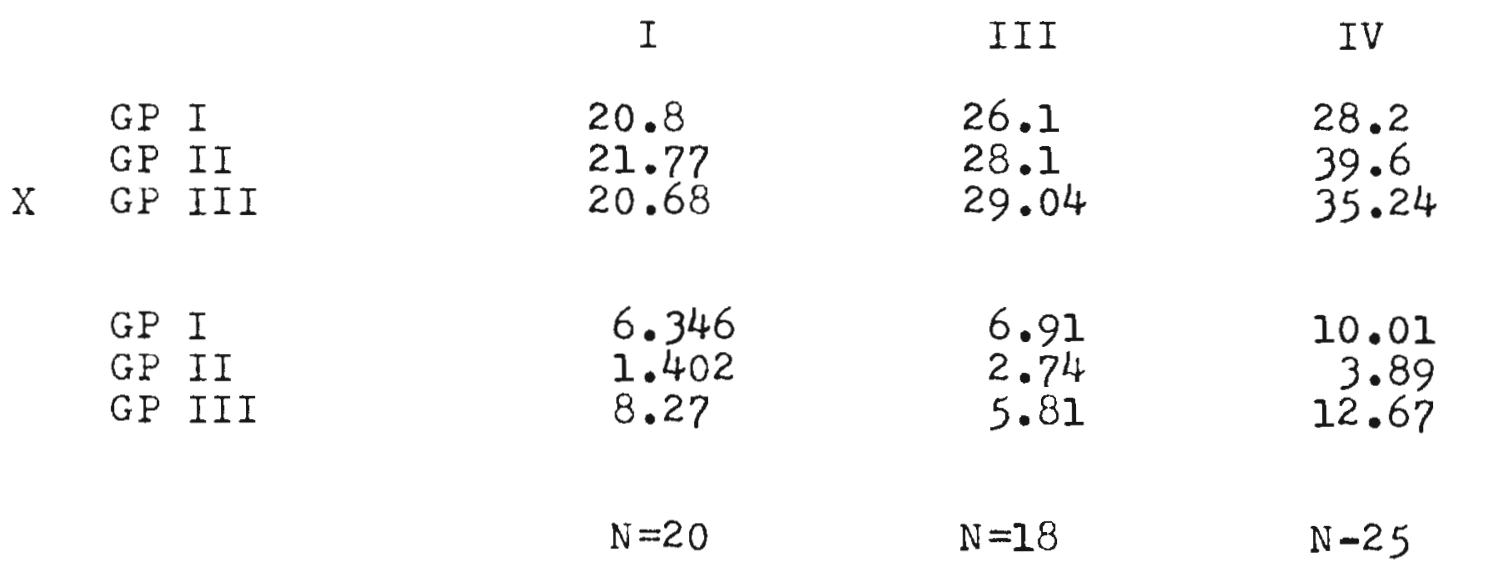


Purpose in Life and a sense of being in control of one's destiny, areas corresponding to the two hypothesized sectors of the will to Ifve concept. In addition, it contained 1 tems reflecting a sense of accomplishment, of selfactualization, of satisfaction in goals already achieved. The label given to this component was "a level beyond" referring to the relationship between the component and Erickson's final stage of development. This component accounted for $5.9 \%$ of the unrotated variance.

Component 4 contains 1 tems which reflect the presence of energy and enthuslasm, as well as a sense of purpose. The label given to this component was "energy level". Th1s component accounted for $5.3 \%$ of the unrotated variance.

Group Differences on Component Scales (One, Three, Four) The following components: "mood state", "a level beyond" and "energy level" were measured across the three groups: Group One living in a nursing home setting; Group Two living in apartment complexes for the elderly; and Group Three living in non-specialized housing in the communtty. The individual scores were computed by including items on each given component with a loading of .50 or above, with negatively welghted 1 tems reflected before summation. Scores were then summed across each group. (Table \#5 presents the means and standard deviations for the three experimental groups on the three component scales.) 
F max values for the three components were as follows: Component I-34.92; Component III-6.33; Component IV-10.57 ( df 2,20). Due to possible v1olation of the homogenlty of varlance assumption, Kruskal-Wallis analyses were performed. The rank totals and $H$ values for the three groups for each of the components is presented in Table 6. An $\mathrm{H}$ value of $13.8, \mathrm{p}<.001$ was obtalned for Component IV "energy level". No other slgnificant differences were found.

Group D1fferences on W11l to L1ve Measure

F max values calculated for the will to Live measures were as follows: Purpose in Life-9.41; W11l to L1ve-3.56; Locus of Control-1.83 (df 2,20). Due to possible violation of the homogenity of variance assumption, a Kruskal-Wallis analysis was performed on the Purpose in Life data. The other two measures, the Self-Rating w1ll to Live measure and the Locus of Control measure, were judged to be not in possible violation of the homogentty of variance assumption, therefore, one-way analyses of variance were performed on this data.

\section{Purpose in Life}

Significant group differences were obtained on the Furpose in Iffe measure $(H=19.4 ; \mathrm{p}<.001 ; \mathrm{d} f=2)$. The rank totals for the three groups on the Purpose in Life measure were $434.5 ; .688 .5$ and 893 , with the community group showing the highest Furpose in Life, the apartment home group the next, and the nursing home group showing the lowest Furpose 


\section{TABLE 6}

\section{Kruskal-Wallis Analysis for \\ Components I, III, and IV}

$$
\text { Group I Group II Group III }
$$

Part 1. Component I

Rank Totals

$$
\begin{array}{ll}
718.5 & 465.5 \\
N=20 & N=18 \\
H=3.05186 & \mathrm{p}<.30
\end{array}
$$$$
\mathrm{N}=25
$$$$
d f=2
$$

Part 2. Component III

$$
\text { Rank Totals }
$$

$$
\begin{aligned}
& 564.5 \\
& N=20 \\
& H=2.77
\end{aligned}
$$

534

$\mathrm{N}=18$

$\mathrm{p}<.30$

$\mathbb{N}=25$

$\mathrm{df}=2$

Part 3. Component IV

Rank Totals

$\begin{array}{ll}408 & 712 \\ N=20 & N=18 \\ H=13.8 & p<.001\end{array}$

408

895.5

$\mathrm{N}=25$

$\mathrm{df}=2$ 
in Life. The Kruskal-Wallis analysis results are presented in Table ?.

\section{W111 to Live}

Significant group differences were obtained on the Self-Rating w1ll to Iive measures $(F=3.99, p<.02 ; d f=2.60)$. The Analysis of Variance for the will to Live data is presented in Table 8. The means of the will to Live measure were $65.2,70.8$, and 82.4 , with the nursing home group showing the lowest will to Live, the apartment group with the next highest will to Live, and the group living in the community showing the highest will to Live. The Neuman-Keuls results are presented in Table 9. Statistical analyses ind1cated that the nursing home group had significantly lower Will to Live than did the private home group. No other differences were found.

\section{Locus of Control}

Analysis of variance results, presented in Table 10, indicate that a significant difference between groups does not exist on this variable $(F=2.9, p<.06, d f=2,60)$, although the results approach significance. The means on the Locus of Control measure for the three groups are as follows: 22.2 , 20.7. 18.5. with the nursing home group showing the most external locus of control, and the private homes showing the most internal locus of control. 
TABLE ?

Kruskal-Wallis Analysis

PIL Data

Group I Group II Group III

Rank Totals

$\begin{array}{lll}434.5 & 688.5 & 893 \\ N=20 & N=18 & N=25 \\ H=19.4 & p<.001 & \text { df }=2\end{array}$


TABLE 8

One Way Analysis of Variance

for Three Groups on W1II to Live

$\begin{array}{lcrccc}\text { Source } & \underline{\mathrm{SS}} & \mathrm{df} & \underline{\mathrm{NS}} & \underline{F} & \text { Prob F } \\ \text { Group } & 3450.558 & 2 & 1725.279 & 3.989 & >.024 \\ \text { Error } & 25947.925 & 60 & 432.465 & & \end{array}$




\section{TABLE 9}

The three groups ordered according to means on the W1II to Live Scale

Newman Keuls comparisons Indicated

$\begin{array}{ccc}\text { Group I } & \text { Group II } & \text { Group III } \\ 65.250 & 70.833 & 82.359\end{array}$

I - I I I

$q=6.5301 * *$

$I-I I$

$q=2.1309 n \cdot s$.

II - III

$q=4.3992 *$ 
TABLE 10

One Way Analysis of Variance for Three groups on Locus of Control

$\begin{array}{lccccc}\text { Source } & \text { SS } & \text { df } & \text { MS } & \text { F } & \text { Prob F } \\ \text { Group } & 154.454 & 2 & 77.227 & 2.888 & >.063 \\ \text { Error } & 1604.393 & 60 & 26.739 & & \end{array}$


Age and Physical Condition

Careful inspection of the data revealed no consistent relationships between reported physical condition and the dependent measures. There appeared to be somewhat of a positive relationship between age and both Purpose in Life and will to Iive, such that the older subjects had greater associated levels of Purpose in Life and Will to Live. Because of between group differences, it was not possible to investigate these relationships in a more systematic fashion, utilizing a combined group format; small within group size made it impossible to obtain meanIngful correlational data, thus, inspection of the data appeared to be the best avallable method of obtalning an indication as to the relationship between these variables and the dependent measures. A larger sample size should be utilized to verify this observational data. See Table 11. 


\section{TABLE 11}

Demographic Differences Across Three Groups

$$
\text { Group I Group II Group III }
$$

Nursing Home Apartment Elderly Private Residences

\begin{tabular}{|c|c|c|c|}
\hline Age Range & $60-95$ & $65-83$ & $60-91$ \\
\hline Mean Age & 78.6 & 72.8 & 70.4 \\
\hline Male/Female & $7 / 13$ & $2 / 16$ & $8 / 17$ \\
\hline $\begin{array}{l}\text { Mean number of } \\
\text { physical com- } \\
\text { plaints }\end{array}$ & 2.05 & 2.4 & 2.4 \\
\hline $\begin{array}{l}\text { Mean number of } \\
\text { years in resi- } \\
\text { dence }\end{array}$ & 2.1 & 5.9 & 20.4 \\
\hline
\end{tabular}




\section{DISCUSSION}

This study sought to begin the process of operationalization of the concept of Will to Live. It was hypothesized that Will to Iive was composed of elements of purpose in life and locus of control. There was in fact a component such as this, Component III "A Level Beyond", suggesting that the hypothesis, based on data both experimental and experiential, drawn from human and animal literature, was essentially correct. The secondary hypothesis regarding the relationship between the Purpose in Life measure and depression was strongly supported. Further, the hypothesis regarding group differences on the various will to Live measures was supported for two of the three scales.

\section{Principle Components Analysis}

The principle components analysis ylelded four components: mood state, locus of control, a level beyond, and energy level. Especially evident in the mood state and energy level Components was the strong inverse relationship between the Purpose in Life measure and the Depression measure, these two variables jointly contributing to these two Components.

Most interesting of all the obtained components was Component III "A Level Beyond". This Component closely approximated the hypothesized Will to Live Component and correlated. 36 with the single item self-rating will to Iive measure. It included items relating to purpose in life, 
locus of control and self-actualization, a factor not included as a primary element in the Will to Live concept. The inclusion of self-actualization items suggests a Component approximating Erickson's final developmental stage, stage elght, orlented toward satisfaction or despair about one's past. However, this Component goes beyond involvement with the past; Included, as well, are items relating to future goals. This finding could be interpreted in several ways: it could suggest that there is a sizeable segment of the elderly population, which, contrary to Erickson's formulation, relate to future goals, as much as do sectors of the non-elderly population. This notion provides support for the Activity proponents' approach to the elderly - an approach which suggests that the elderly are not substantially different from the non-elderly adult population in their need for activities and goals. A second interpretation of this finding might be that Erickson's final stage of development oriented only toward the past, if it does indeed occur, occurs immediately preceding death. One implication derived from the results of the principle components analysis regards the multi-dimensional nature of Crumbaugh's Purpose in Life measure. This was suggested by the way in which Furpose in Life items divided roughly into thirds, spread over three of the four components, suggesting that purpose in life, as conceived by Crumbaugh, is a complex concept. Further principle components analyses or factor analyses of Crumbaugh's scale are suggested to 
examine more closely the complexities of the Purpose in Iife concept.

\section{Group Differences}

Group analyses showed the community group to have significantly higher will to Iive, significantly higher Purpose in Life, and significantly greater energy level than did the nursing home group. These results are consistent with hypotheses which would predict higher performances on Will to Live measures to be associated with living situations which support and promote a sense of personal autonomy and self-direction.

Although the locus of control results were not s1gnificant, they were in the expected direction and approached significance. The locus of control measure used in this study was a generallzed measure. It may well be that if a more personally-orlented locus of control measure were used, group differences on that measure would become much more apparent.

of most interest in reviewing the group data was the pattern of differences between the community and apartment groups on the various will to Live measures. With the community group showing higher self-rated will to Live than the apartment dwellers, the apartment group showed higher purpose in life and the community group showed higher internal locus of control. If one begins with the hypothesis that purpose in life and locus of control are component parts of Will to Live, it could be suggested that of these two 
parts, locus of control, rather than purpose in $11 \mathrm{fe}$, was the part more likely to be associated with and co-vary with the self-rating will to Live measure. At the present stage of investigation, however, such statements must be considered to be highly speculative in nature.

\section{Institutionalization of the Elderly}

Above and beyond the issue of arailable autonomy in the various group settings, there exists another 1ssue that being the issue of institutionalization, relating primarily to the nursing home group. Institutionalization carries with it special problems for the elderly and is an area which has received special study on 1 ts own. Strnad (1973) has discussed the loss of independence and freedom of action as one of five major problem areas for the institutionalized elderly. Wolk and Reingold (1975) have discussed the loss of previous life style as being a serious problem area for the institutionalized elderly.

Among other differences reported among institutionalized elderly is a study on locus of control among institutionalized elderly, which concluded that, as opposed to non-institutionalized populations, in the institutionalized. external locus of control is associated with "adjustment". Results from the present study suggest the opposite - that although having more external levels of locus of control than non-institutionalized groups, the institutionalized elderly also demonstrate lower Purpose in Life and self-rated Will to Live and higher levels of depression, all associated 
with lower rather than higher levels of adjustment, although the levels of depression obtained reached only those associated with low or mild degrees of depression.

\section{Range of Depression}

This finding - the low level of depression obtained for Group I in the present study - was also surprising. given the reports of the prevalence of depression in the elderly. The selection of subjects - of only those able and willing to carry on a rather lengthy interview procedure undoubtedly had an influence on restricting the range of depression obtained in the present study.

\section{Purpose in Life and Depression - The Relationship}

It was hypothesized that the purpose in life measure of the Will to Live measures would show a negative relationship to Depression since experientially, the loss of Will to Live so closely resembles a severely depressed state. That did, in fact, occur with the obtalned correlation between Purpose in Iife and depression (-.83). The strength of the negative correlation between Purpose in Life and depression suggests that these are not merely related variables, but rather that they represent the bipolarity of a single variable. Although Crumbaugh (1964) obtained similar results which found the Depression Scale of the MMPI significantly inversely correlated with the Purpose in Life Scale, he disputed the notion that the Purpose in Life measure "was an indirect measure of depression". He discussed the complexity 
of the interrelationship between the varlables and that lack of Purpose in Life may be both cause and effect of depression. Further, he described lack of purpose in life as being both a more generic term than depression and a more specific. Inadequate technique of adjustment to conflict. Despite Crumbaugh's explanations, another depression measure, the Beck Depression Inventory, has been shown to have a strong negative correlation with the Purpose in Life measure. These findings provide a strong basis for the thesis that depression is a bipolar rather than a unipolar dimension. with Purpose in Life at one end of the continuum and depression at the other.

Earlier in this paper there were several descriptions of incidents in which an individual who had been coping adequately suddenly gave up any attempt at survival in a difficult situation. It appears that there are many situations in which lack of Purpose in Life is intimately related to a syndrome closely resembling deep depression which 1s, in some cases, an 1mmediate precursor to death. It is in no way necessary to suggest that a lack of Purpose in Life is always related to depression. Or, sald another way, not all depressions are related to lack of Purpose in Life. It is an interesting notion, however, to consider a certain proportion of depressed individuals as having, instead, a low Purpose in Life. This is especially relevant to the elderly population, since it is the elderly who are frequently deprived of their autonomy and of many of the goals they directed themselves toward all their lives. 
The notion of lack of Purpose in Life as being related to depression in the elderly is, 1t appears, in opposition to the position of the disengagement theorists (Neugarten, 1972, Cumming and Henry, 1961). These theorists suggest that an elderly person naturally goes through the process of disengagement from his surroundings as a natural and adaptive reaction to the aging process. The alternative to this, supported by the results of this research, is that the elderly are no different from people at other ages and have a need for purposes and goals in their lives; when these goals are not present, depression is likely to be.

\section{Practical Implications}

Practical implications for the elderly, related to these findings about Purpose in Life, encompass a wide-range of possibilities. One of these possibilities may include establishment of intergenerational housing programs, as they have in Norway (Mortensen, 1976). Th1s sort of housing program would allow for the natural intergenerational dependencles and role functions, providing the elderly with a noncontrived purpose in ilfe.

Another possibility is suggested by the Sorlet theory of treatment of the elderly (Polk, 1976) which involves provision of opportunity for work in old age homes. For their work, which is not mandatory, they recelve a share in the earnings of whatever they help manufacture. In add1- 
tion. Soviets are encouraged to delay their retirement and to continue to work as long as they are able.

With relation to those individuals no longer capable of physical work, Butler (1974) speaks of the elderly years as an opportunity for reflection, for integration of a lifetime of learning and life experience. Part of this function could be fulfilled within the family. Finally, Kurtz and Wolk (1975), in stating that continued growth is the key to continued life satisfaction in the elderly, imply perhaps one of the areas of possible ald for the elderly may be through the educational system, by providing educational opportunities for the elderly.

\section{Further Implications of the W1Il to Live Concept}

Given the structure of w1ll to Live as has been suggested in this research, if we knew what a person's locus of control history had been, and we knew what degree of purpose in life existed, theoretically we should be able to predict with a degree of accuracy the segment of the population least likely to survive an ordeal situation as well as that most likely to survive 1t. There are practical implications which follow from this. If we were able to 1dentify "at risk" populations of the elderly (or for that matter for other groups under stress), we would perhaps be better able to advise with regards to some very critical life decisions for the elderly: elective surgery, change of living situation, etc., with more knowledge than is now avallable as to how stress may affect the individual in question. 


\section{Limitations of Current Findings}

This research has been an initial venture into a new area, attempting a new integration of concepts and as such doesn't allow for the degree of rigor possible at later stages of development of an area. Further investigations into this area w1ll allow for greater refinement of measures and concepts.

Some of the areas not dealt with in the present study included consideration of effects of: medication, ethnic background, and degree of family involvement of the subject populations. All of these variables could be reasonably expected to have potential impact upon the W1Il to Live.

The interrelationship between age and sex and W1Il to Live was examined in a non-statistical fashion in this study - due to constralnts associated with sample size. Physical condition was examined through a selfreport device. No objective measure of physical state was utilized in this study.

In general, the limitations of this study reflect the as yet undeveloped state of will to Live as a researchable area and the exploratory status of this study as a first venture into that area.

\section{Implications for Future Research}

W1ll to Live has shown heuristic possibilities as a researchable area. The significant results obtained using 
an undeveloped self-rating measuring device has suggested that further investigations in this area may well promise to be very rewarding. In order to further develop the instrument, it may be most expedient to utilize the very accessible college sophomore before returning to the real world to study less available, more interesting populations such as the physically 1ll, psychiatric populations, and a wider sample of the elderly population. Further studies could as well provide an evaluation of sex differences on the W1Il to Live measures, another area which was beyond the scope of this study.

Further studies should consider an assortment of variables not included in this study because of their potential influence upon and relationship to the Will to Live. Included among these are: medication, ethnic background, family involvement, activity level, and objective measurements of physical condition. Larger sample sizes in future research would allow for close examination of age and sex and their relationship to Will to Live.

The concept of depression and purpose in life as a bipolar measure is a very provocative one. The relationship should be further explored with other populations to obtain a clearer sense of the range of applicability as well as to explore the possibility of utilization of the purpose in iffe scale as an alternative to existing depression measures. No existing measures are well suited to the elderly because of their inability to separate the physical and performance 
Iimitations associated with the aging process from those generally assoclated with the psychological syndrome of depression. 
REFERENCES 
Abdo, E. \& Dills, J. et al. Elderly women in institutions vs. those in public housing: comparison of personal and social adjustment. Journal of Am. Geriatric seciety, 1973, 21, 81-87.

Barrett, J. Gerontological Psychology. Charles C. Thomas, Springfield, IIl., 1972.

Beck, A. T. et al. An inventory for measuring depression. Arch. of Gen. Psychiatry, 1961, 4. 561-571.

Beck, A. T. The Diagnosis and Manarement of Depression. University of Penn. Press, Philadelphia, Pa., 1967.

Beck, A. T. Depression: Clinical, Experimental and Theoret1cal Aspects. Harper \& Row, N.Y., N.Y.,1967.

Beckman, Allan C. Role loss. Powerlessness and Depression amons older men and women. Dissertation Abstracts International, 1973 (JuI), Vol. 34 (I-A) 419.

Birren, J. et al. Research, demonstration and training issues and methodology in social gerontology. The Gerontolog1st, 1972, 49-83.

Blau, Z. Old Age in a Changing Society. New York: New Viewpoint, 1973.

Brady, J.V. et al. Avoldance behavior and the development of sastro duodenal ulcers. Journal of the Experimental Analysis of Behavior, 1958, 1, 69-72.

Butler, Robert $N$. Successful Asing and the role of the life review. Journal of Am. Geriatric Soc1ety. 1974 (Dec), Vol. $22(12), 529-535$.

Cannon, W. Voodoo Death. Psychosomat1c Medicine, 1957, 19, $182-190$

Clark, M. The case: Did Watergate make him sick? Newsweek, Nor. 11, 1974, 28-29.

Coleman, J. C. Iife stress and maladaptive behavior. American Journal of Occupational Therapy, 1973, 27, 169-180.

Crumbaugh. J. \& Maholick. I. An experimental study in existentialism: The psychosomatic approach to Frankl's concept of noogenic neurosis. Journal of clinical Psychology. 1964, 20, 200-207. 
Crumbaugh, J. Cross validation of I'urpose in Lif'e l'est. based on Frankl's concepts. Journal of Individual Fsychology, 1968, 24, 74-81.

Cumming, E. and Henry, W. E'. Growing old: The process of D1sengagement. New York: Bas1c Books, 1961.

Curtin. S. R. Nobody Ever Died of old Age. Little, Brown \& Co.. Boston, 1972 .

Dawson, A. \& Baller, W. Relationship between creative activity and the health of elderly persons. Journal of Psychology, 1972, 82, 49-58.

Des Pres, Terrence. The Survivor. Oxford University Press, N. Y.. 1976.

Dowd, J. J. Aging as exchange--a Preface to Theory. Journal of Gerontology, 1975. 30/5, 584-594.

Eisdorfer, C. In Handbook of Community Mental Health. Mental health in later IIfe. Appleton-Century Crofts. N. Y.: N. Y.. 1972 .

Ewing, I. S. Flghting and death from stress in a cockroach. Sclence, 1967, 155, 1035-1036.

Felton, B. \& Kahana, E. Adjustment and situationally bound locus of control among institutionalized aged. Journal of Gerontology. 1974, 29, 295-301.

Frankl, V. E. The Doctor and the Soul. Alfred A. Knopf, Inc.. N. Y.. N.Y.. 1955 .

Frankl, V. E. Beyond self actualization and self expression. Journal of Existentlal Psychology. 1960, 1, 5-20.

Frankl, V.E. Mans' Search for Meaning. Washington Square Press. N. Y.. N.Y.. 1963.

Frankl, V.E. Psychotherapy and Ex1stent1al1sm; Selected Fapers on Logotherapy. Simon \& Schuster, 1967.

Fromm, E. The Heart of Man: Its Genius for Good and Evil. Harper \& Row, N. Y., N. Y., 1964.

Ginspag. S. Cardiogram or psychogram; which do you really need? Menninger Perspective, 1973. 414, 4-8.

Graney, M. \& Graney, E. Scallng adjustment in older people. Inter. Joumal of Asing and Human Development, 1973, 4. 351-359. 
Gubrium, J. Toward a socio-environmental theory of aging. The Gerontologist, 1972, 12, 281-284.

Gunther, J. Death be not Proud. Harper \& Row, N. Y., N.Y., 1949.

Hall, C. S. and Lindzeg, G. Theories of Personality. New York, John Wiley \& Sons, Inc., 1970.

Havighurst, R. J. Successful aging. Gerontologist, 1961, 1. 8-13.

Hutschnecker, A. A. The Will to Live. Simon \& Schuster, N. Y.. N. Y., $19 \overline{5 I}$

Huyck, M. Growing Older; What You Need to Know About Aging. Englewood Cliffs, New Jersey, Prentice-Hall, Inc.. 1974.

James, W. H. Internal vs. External control of reinforcement as a basic variable in learning theory. Unpublished Doctoral Dissertation, Ohio State University, 1957.

James, W. H. et al. Effect of internal and external control upon changes in smokey behavior. Journal of Consulting Psychology, 1963, 29, 127-129.

Jan1s, I. Psychological Stress. John Wiley \& Sons, Chicago, Ill., 1958.

Jewett, S. Longevity and the longevity syndrome. The Gerontolog1st, 1973, 13, 91-99.

Kotchen, T. A. Existential mental health: An empirical approach. Journal of Individual Psychology, 1960, 16, $174-181$.

Kurtz, J. and Wolk, S. Continued Growth and Life Satisfaction. Gerontologist, 1975 (Apr.), Vol, 15 (2), 129-131.

Kuypers, J. Internal-external locus of control, ego functioning and personality characteristics in old age. The Gerontologist, 1972, 12, 168-173.

Kuypers, J. Psychological health in old age: By whose definition? American Journal of Orthopsychiatry. 1974, 44, 262-263.

Larson, C. Alienation and Public Housing for the Elderly. Int. Journal of Aging and Human Dev.. 1974 (sum.). Vol. 5(3). 217-230.

Lawton, $M_{\text {. }}$ and Cohen, J. The generality of housing impact on the well being of older people. Journal of Gerontology, 1974, 29, 194-204. 
Leftcourt. H. M. The function of the illusions of control and freedom. Am. Psychologist, 1973, 28, 417-425.

Levin. S. Depression in the aged: a study of the salient external factors. Geriatrics, 1963, 302-307.

Lifrak. S. T. The effects of interpersonal stress on repression-sensitization. Unpublished Doctoral Dissertation. University of Rhode Island, 1970.

MacDonald, A. P. and Tseng, M. Dimmensions of Internal vs. External Control Revisited. Catalogue of Selected Documents in Psychology, 1974 (winter), Vol. 4, 13.

Madd1, S. R. Personality Theories: A Comparative Analysis. Dorsey Press, Homewood, III., 1968.

Maddox, G. et al. Aging and Individual Differences: A longitudinal analysis of soc., psych., and physiological indicators. Journal of Gerontology, 1974 (Sept.), Vol. $29(5), 555-563$.

Maslow, A. H. Toward a Psychology of Being. Litton Educational Publishing. Inc.. N. Y., N. Y.. 1968.

May, R. Love and WIII. W. W. Norton \& Co., N. Y., N. Y.. 1969.

Mortensen, Kris. "Scandinavia: The best, but not Ferfect". The Providence Sunday Journal, Nov. 14, 1976, A-13.

Neugarten et al. Personality in Middle \& Late Life: Empirical Studies. New York, Atherton Press, 1964.

Neugarten, Bernice L. Personality and the Aging Process. The Gerontologist, 12, 1972, 9-15.

Overmier, J.B. \& Seligman, M. Effects of inescapable shock upon subsequent escape and avoldance responding. Journal of Comparative and Physiological Psychology, 1967,63.

Palmore, E. The effect of aging on activities and attitudes. The Gerontologist, 8, 1968, 259-263.

Palmore, E. \& Lulkart, C. Health and Social Factors related to Iife satisfaction. Journal of Health and Social Behavior, 1972, 12, 68-80.

Pierce, R. \& Clark, M. Measurement of morale in the elderly. Int. Journal of Aging and Human Development, 1973, 4.

Folk. P. "Soviets believe in keeping their Elderly at Work". The Providence Sunday Journal. Nov. 14, 1976, A-13. 
Prochaska. J. O. Symptoms and dynamic cues in the implosive treatment of test anxiety. Journal of Abnormal Psychology, 1971, 27 (2), 133-142.

Richter, C. On the phenomenon of sudden death in animals and man. Psychosomatic Med1c1ne, 1959, 19, 191-198.

Riley, M. \& Foner. A. Aging and Society. Vol. 1: An inventory of research findings, New York: Russell Sage Foundation, 1968.

Rotter, J. B. Generalized expectancies for internal vs. external control of reinforcement. Psychological Monographs, 1966,80 , (1 whole No. 609).

Schneidman. E. Deaths of Man. N. Y. Times Book Co.. N. Y.. N. Y.. 1973.

Sel1gman, M. \& Overme1r, S. Fallure to escape traumatic shock. Journal of Experimental Psychology, 1967. 24,

Seligman, M. et al. The alleviation of learned helplessness in the dog. Journal of Abnormal and Social Psycholozy. 1968, 23, 257-262.

Seligman, M. Submissive death: Giving up on I1fe. Psychology Today, 1974, $4,80-85$.

Seligman, M. Helplessness: on depression, development and death. W. H. Freeman, N. Y., N. Y.. 1975.

Sherman, S. Methodology in a study of residents of retirement housing. Journal of Gerontology, 1973, 28, 351-358.

Smith, E. D. Handbook of Asing for Those Growing Old, and for Those Concerned with Them. Harper \& Row, N. Y.. N. Y.. 1972 .

Strnad, M. Differential Approaches to new arrivals in homes for the elderly. C'eskoslovenska' Psychmatice'. 1973 (June). Vol. 69 (3). 195-198

Velicer, Wayne F. Determining the number of components from the matrix of partial correlations. Fsychometrika. Vol. 41 (3), sept., 1976.

Weiss, J. M. Effects of coping behavior in different warning signal conditions on stress pathology in rats. Journal

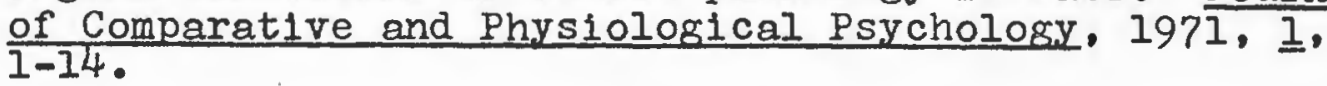
Wolfe, K. Personal Communication. 1974 
Wolk, R. and Reingold, J. The course of life for old people. Journal of the Amexican Geriatrics Soc1ety. 1975 (Aug.), Vol. $23(8), 376-379$.

Wolk, S. and Kurtz, J. Positive Adjustment and Involvement during asing and expectancy for internal control. Journal of Consulting and Clinical Ysych, 1975 (Apr.), Vol. $43(2), 173-178$.

Wolpe. J. and Lazarus, A. Behavior Therapy Techniques. New York: Pergamon, 1969.

Woodward, $\mathrm{H}$. et al. "Loneliness and the elderly as related to housing". Gerontologist. 1974 (Aug.), Vol. 14 (4), 349-351. 
APPENDIX 
1. Age

2. $\operatorname{sex}$

3. Marital Status

4. Living Situation Room in home Apartment in complex Non-specialized (specify)

5. Length of time at present residence

6. Rated degree of privacy/autonomy in living quarters

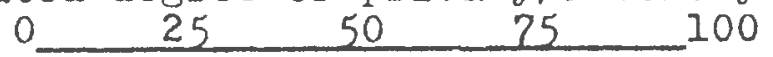

7. Last grade of school completed

8. Are you now, or were you at one time employed?

9. What sort of work did you do?

10. How long has it been since you held a job?

11. If you are or have been married, what sort of work did your spouse do?

12. What was your father's occupation?

13. How old were your parents when they died? Mother F'ather

14. What was the most difficult time in your life so far?

15. What made it especially difficult?

16. How did you handle it?

17. What would be a difficult situation for you to handle at this point in your life?

18. How do you think you'd handle it?

19. Do you have any physical problems at the present time? eye sight hearing arthritis high blood pressure diabetic heart trouble other stomach trouble 
20. As you look back on your iffe, in general would you say it has been:

Very happy Moderately happy Average Unhappy 
For each of the following statements, circle the number that would be most nearly true for you. Note that the numbers always extend from one extreme feeling to its opposite kind of feeling. "Neutral" implies no judgment either way. Try to use this rating as little as possible.

1. I am usually:

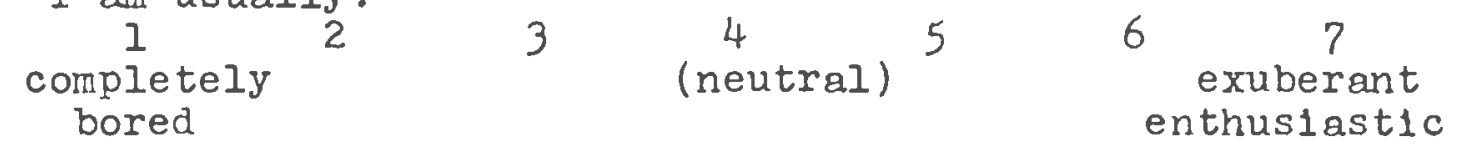

2. Life to me seems:

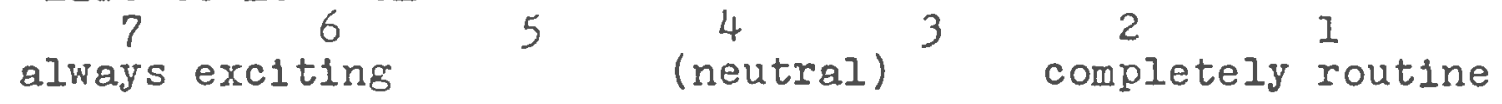

3. In life I have: no goals or alms at $\begin{gathered}3 \\ \text { all }\end{gathered}$ (neutral) $^{4}$ very clear goals \& alms

4. My personal existence is:

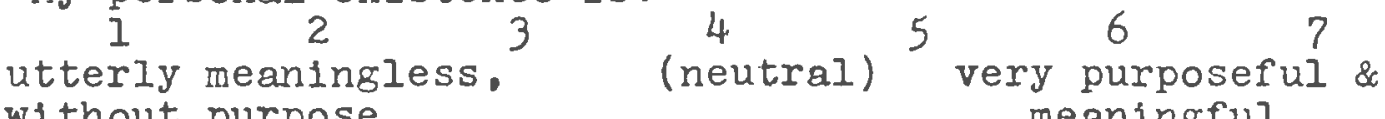
w1thout purpose meaningful

5. Every day is:

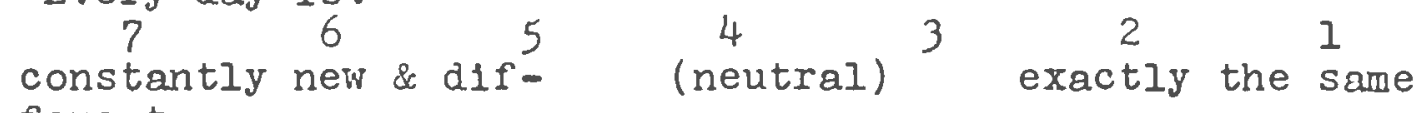
ferent

6. After retiring I would:

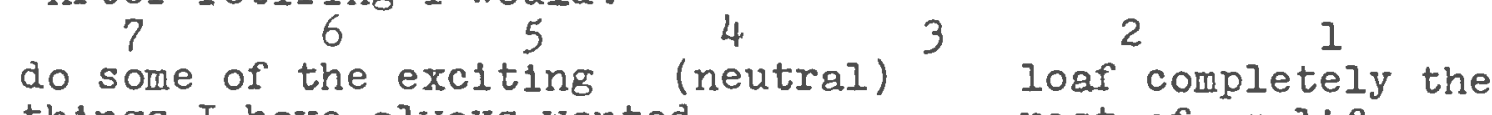
things I have always wanted to rest of my life

7. If I could choose. I would: prefer never to have been born

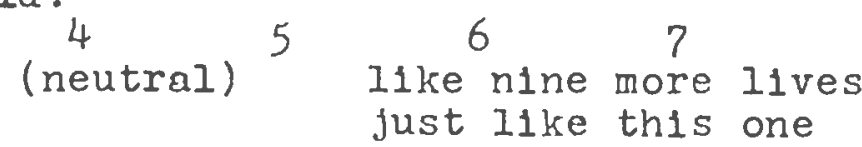

8. In achieving Iife goals I have:

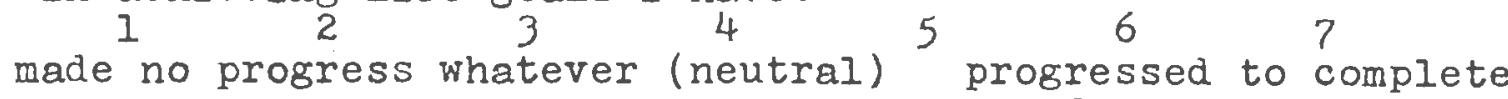
fulfiliment 
9. Wy Iife is:

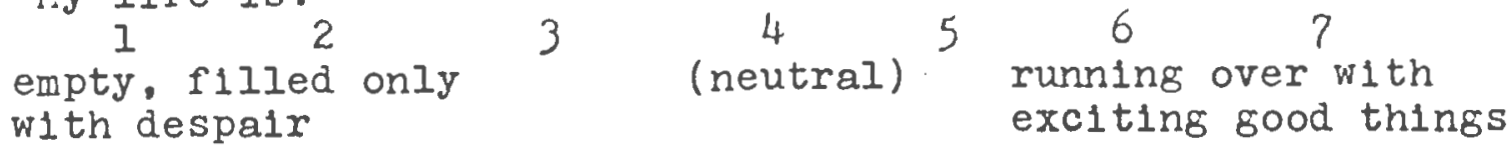

10. If I should die today. I would feel that my Iffe has been: $\begin{array}{ccccc}7 & 6 & 5 & 4 & 3 \\ \text { very worthwhile } & & \text { (neutral) } & \text { completely worthless }\end{array}$

11. In thinking of my life, I: $\begin{array}{ccccc}1 & 2 & 3 & 6 & 7 \\ \text { often wonder why I exist } & \text { (neutral) } & 5 & 6 & 6\end{array}$ for my being here

12. As I view the world in relation to my $11 \mathrm{fe}$, the world: $\begin{array}{lllllll}1 & 2 & 3 & 4 & 5 & 6 & 7\end{array}$ completely confuses me (neutral) fits meaningfully with my IIfe

13. I am a:

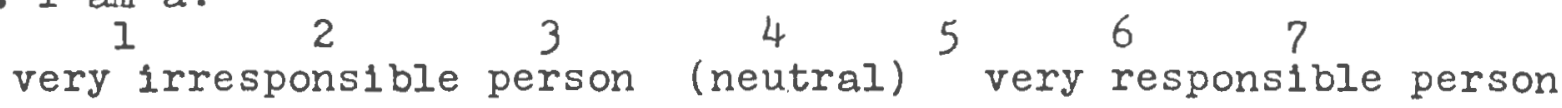

14. Concerning man's freedom to make his own choices. I believe man 1s:

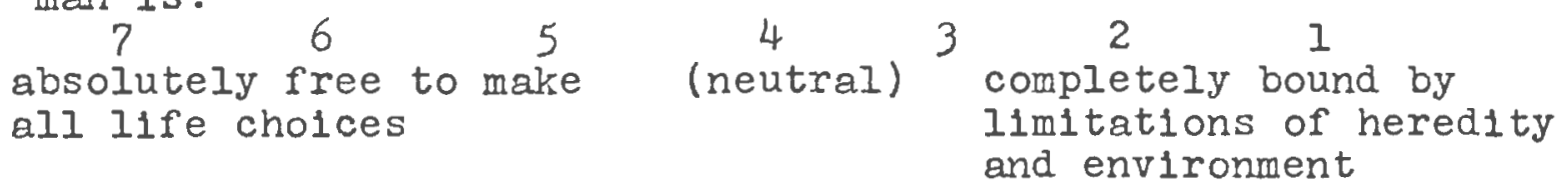

15. W1th regard to death, I am:

7
prepared and unafraid ${ }^{6}$ (neutral) ${ }^{3}$ unprepared and frightened

16. With regard to suicide, I have:
$\begin{array}{cc}1 & 2 \\ \text { thought of } 1 t & 3 \\ & \end{array}$
as a way out
$\begin{array}{ccc}4 & 6 & \\ \text { (neutral) } & 5 & \text { never given it a }\end{array}$ second thought

17. I regard my ability to find a meaning, purpose, or mission in life as:
very great
5

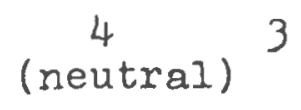
$\begin{array}{cl}2 & 1 \\ \text { practically } & \text { none }\end{array}$

18. My I1fe is:
in my hands, and $I$ am
in control of $1 t$
4
(neutral) ${ }^{3}$ out of my hands \& con- trolled by external factors

19. Facing my dally tasks is:
$\begin{array}{cl}7 & 6 \\ \text { a source of pleasure }\end{array}$
and satisfaction
(neutral) $^{4}$ a painful and boring experience


20. I have discovered:

$\begin{array}{lccc}1 & 2 & 4 & 5 \\ \text { no mission or purpose } & 3 & 6 & 7 \\ \text { in life } & \text { (neutral) } & \text { clear cut goals and a } \\ \text { satisfylng life purpose }\end{array}$


Beck Inventory

Please select the statement in each group of statements that seems to fit you best at the present time. Circle the number in front of that statement.

A.

0 . I do not feel sad

I I feel blue or sad

2a I am blue or sad all the time and I can't snap out of $1 t$

2b I am so sad or unhappy that it is very painful

3 I am so sad or unhappy that I can't stand it

B.

0 I am not particularly pessimistic or discouraged about the future

1 I feel discouraged about the future

2a I feel I have nothing to look forward to

$2 \mathrm{~b}$ I feel that I won't ever get over my troubles

3 I feel that the future is hopeless and that things cannot improve

C.

- I do not feel like a failure

I I feel I have falled more than the average person

$2 a$ I feel I have accomplished very little that is worthwhile or that means anything

$2 b$ As I look back on my life, all I can see is a lot of fallures

3. I feel I am a complete failure as a person (Parent, husband, wife)
D.

- I am not particularly dissatisfied

la I feel bored most of the time

Ib I don't enjoy things the way I used to

2 I don't get satisfaction out of anything anymore

3 I am dissatisfied with everything

E.

- I don't feel particularly guilty

1 I feel bad or unworthy a good part of the time

2a I feel quite guilty

2b I feel bad or unworthy practically all the time now

3 I feel as though I am very bad or worthless

F.

0 I don't feel I am being punished

I I have a feeling that something bad may happen to me

2 I feel I am being punished or will be punished

3a I feel I deserve to be punished

3b. I want to be punished 
G .

- I don't feel disappointed in myself

la I am disappointed in myself

Ib I don't like myself

2 I am disgusted with myself

3 I hate myself

$\mathrm{H}$.

- I don't feel I am any worse than anybody else

I I am very critical of myself for my weaknesses or mistakes

2a I blame myself for everything that goes wrong

$2 \mathrm{~b}$ I feel I have many bad faults

I. I don't have any thoughts of harming myself

1 I have thoughts of harming myself but I would not carry them out

2a I feel I would be better of $f$ dead

$2 b$ I have definite plans about committing suicide

2c I feel my family would be better off if I were dead

3 I would kill myself if I could

J

0 I don't cry any more than usual

1 I cry more now than I used to

2 I cry all the time now. I can't stop it

3 I used to be able to cry but now I can't cry at all, even though I want to
$K$.

0 I am no more 1rritated now than $I$ ever am

1 I get annoyed or irritated more easily than I used to

2 I feel irritated all the time

3 I don't get irritated at all the things that used to irritate me

L.

- I have not lost interest in other people

1 I am less interested in other people now than I used to be

2 I have lost most of my interest in other people and have little feeling for them

3 I have lost all my interest in other people and don't care about them at all

M.

0 I make decisions about as well as ever

1 I am less sure of myself now and try to put off making decisions

2 I can't make decisions any more without help

3 I can't make decisions at all anymore 
N .

- I don't feel I look any worse than I used to

I I am worried that I am looking old or unattractive

2 I feel that there are permanent changes in my appearance and they make me look unattractive

3 I feel that I am ugly or repulsive looking

0 .

0 I can work about as well as before

la It takes extra effort to get started at doing something

Ib I don't work as well as I used to

2 I have to push myself very hard to do anything

3 I can't do any work at all

$P$

- I can sleep as well as usual

I I wake up more tired in the morning than I used to

2 I wake up $1-2$ hours earlier than usual and find it hard to get back to sleep

3 I wake up early every day and can't get more than 5 hours sleep

Q. I don't get any more tired than usual

1 I get tired more easily than I used to

2 I get tired from doing anything

3 I get too tired to do anything

R.

0 . My appetite is no worse than usual

1 My appetite is not as good as it used to be

2 My appetite is much worse now

3 I have no appetite at all anymore
3

0 I haven't lost much weight, if any, lately

1 I have lost more than 5 pounds

2 I have lost more than 10 pounds

3 I have lost more than 15 pounds

T.

- I am no more concerned about my health than usual

I I am concerned about aches and pains or upset stomach or constipation or other unpleasant feelings in my body

2 I am so concerned with how I feel or what I feel that its hard to think of much else

3 I am completely absorbed in what I feel

U.

0 I have not noticed any recent change in my interest in sex

1 I am less interested in sex than I used to be

2 I am much less interested in sex now

3 I have lost interest in sex completely 
Below are a number of statements about various topics. They have been collected from different groups of people and represent a variety of opinions. There are no right or wrong answers to this questionnaire: for every statement there are large numbers of people who agree and disagree. Please indicate whether you agree or disagree with each statement as follows :
Circle SA if you strongly agree
Circle A if you agree
Circe $D$ if you disagree
Circle SD if you strongly disagree

Please read each 1 tem carefully and be sure that you indicate the response which most closely corresponds with the way you personally feel.

1. Many times I feel that we might just as well make many of our decisions by flipping a coin.

SA

A

D

$S D$

2. Getting a good job seems to be largely a matter of being lucky enough to be in the right place at the right time. $\mathrm{SA}$ A

D $S D$

3. It is difficult for ordinary people to have much control over what politicians do in office.

$\mathrm{SA}$

A

$\mathrm{D}$

$S D$

4. It isn't wise to plan too far ahead because most things turn out to be a matter of good or bad fortune anyhow.
SA
A
$\mathrm{D}$
SD

5. When things are going well for me I consider it due to a run of good luck.
SA
A
D
$S D$

6. I have usually found that what is going to happen will happen regardless of my actions.

$\mathrm{SA}$

A

D

$S D$ 
7. Success is mostiy a matter of getting good breaks. $\mathrm{SA}$ A $\mathrm{D}$ $\mathrm{SD}$

8. There's not much use in worrying about things... what w111 be w1II be.
$\mathrm{SA}$
A
D
$\mathrm{SD}$

9. Success in dealing with people seems to be more a matter of the other person's moods and feelings at the time rather than one's own actions.
SA
A
D
$\mathrm{SD}$

10. I think that life is mostly a gamble.
SA
A
$\mathrm{D}$
SD

11. Many times I feel that I have little influence over the things that happen to me.
$\mathrm{SA}$
A.
D
SD 
Will Scale

The human will has been sald to be a strong force in peoples' lives: helping them through very difficult situations: helping them accomplish goals which they ordinarily would not have been able to achieve.

With "100" being the most "Will" anyone could have, and "0" being the least, how much "will" would you say that you have at the present time? Place an " $x$ " at the appropriate spot. 